\title{
Milliyetçiliğin İnşası ve Sinema: Fetih 1453 Filmi Örneği ${ }^{1}$
}

\author{
DOI: 10.26466/opus.535594 \\ * \\ Mustafa Aslan $^{*}$ \\ ORCID: $\underline{0000-0001-5322-767 X}$
}

* Dr. Öğretim Üyesi, Aydın Adnan Menderes Üniversitesi / Aydın / Türkiye E-Posta: maslan@adu.edu.tr

Öz

Toplumsal koşulların bir çıktısı olarak değerlendirilen milliyetçilik, toplumdan ayrı ve bağımsız bir olgu değildir. Milli anlatılar, yeni kuşağa övünülmesi gereken bir millete mensup olduğunu anlatır ve bireyi milliyetçi ideolojinin çizdiği sinırlarm içinde tutar. Kitle iletişim araçlarl; radyo, televizyon, gazete, sinema ve son dönemde sosyal medya, toplum adına ve toplum için gündem belirleme ve algı oluşturma görevini en etkili şekilde gerçekleştirmektedirler. Bu araçlar diğer ideolojileri olduğu gibi milliyetçi ideolojiyi de yeniden üretmeleri bakımından önemlidirler. Toplumsal yaşamdaki milliyetçi söylemi yeniden üreten araçlardan biri de sinemadır. İnşa etmeye çalıştığ gerçekliği geniş, kitlelere ulaştırma gücü dolayısıyla sinema ideolojik bir araçtır aynı zamanda. Sinemasal anlatıda kullanılan neredeyse sonsuz sayıdaki gösterge ve estetik anlayış, filmin anlamın doğrudan etkilemektedir. Türk sinemasında milliyetçi temayı ișleyen filmlerde kullanılan göstergelerin ve estetik anlayışın tespit edilmesi bu araştırmanın temel amacın oluşturmaktadır. Bu kapsamda dünya ve Türk tarihi açısından önemli bir yeri olan İstanbul'un fethinin işlendiği Fetih 1453 filmi analiz edilecek ve milliyetçi söylemin nasıl inşa edildiğine bakılacaktır.

Anahtar Kelimeler: Sinema, Milliyetçilik, Sinemasal Estetik, Estetik

\footnotetext{
${ }^{1}$ Bu makale yazarın 2015 yılında Selçuk Üniversitesi Sosyal Bilimler Enstitüsünde yaptığı Sinemada Milliyetçilik Ve Estetik: Türk Sinemasındaki Milliyetçi Filmlerin Analizi doktora tezinden üretilmiştir.
} 


\title{
The Construction of Nationalism and Cinema: The Case of the Conquest 1453
}

\begin{abstract}
Nationalism has been evaluated as an outcome of social conditions and positioned as a phenomena that is separate and independent from society. One of the tools that reproduce nationalist discourse in social life is cinema. National narratives, it tells that it belongs to a nation that has to be proud of the new generation and keeps the individual within the boundaries drawn by the nationalist ideology. Mass media; radio, television, newspaper, cinema and social media, the most effective way of setting the agenda and creating perception for the society and society. These tools are important for the reproduction of nationalist ideology as well as other ideologies. The movies which come out at the same time in the four corners of the world can transmit the realities which they try to build to large masses, and the stories themselves can be an ideological vehicle by using universal indicator systems. Almost infinite number of indicators used in the cinematic narrative and aesthetic understanding affects directly the meaning of the movie. The deduction of the indicators used in Turkish Cinema movies functioning nationalistic themes and esthetics understanding constitute the primary objective of the study. In this context, Fatah 1453 film will be analyzed and how the nationalist discourse is constructed.
\end{abstract}

Keywords: Cinema, Nationalism, Cinema Aesthetics, Aesthetics 


\section{Giriş}

Matbaanın icadıyla beraber yazının yaygınlaşması, milliyetçi düşüncenin geniş kitlelere ulaşmasını ve milliyetçi ideolojinin kitleselleşmesini beraberinde getirmiştir. Sosyolojik bir kavram olan milliyetçilik, toplumsal koşulların bir çıktısı olarak değerlendirilmeli, toplumdan ayrı ve bağımsız bir yapı olarak görülmemelidir. Milliyetçiliği toplumsal hayattan soyutlayarak sadece bir düşünce biçimi olarak ele almak millet ve milliyetçiliğin anlamını daraltmaktadır. Hâlbuki bu kavramların siyaset dışında hayatımızı etkileme gücü yadsınamayacak kadar fazladır. Söz konusu bu söylem hayatın her alanında kendisine bir karşılık bulur.

Bireyin dünyasında, bir topluluğa aidiyeti sağlamak için, milliyetçi ideolojinin güçlü bir geçmişe ihtiyacı vardır. İhtiyaç duyulan bu geçmiş milleti birbirine ve geleceğe kuvvetle bağlar. Milli anlatılar, övünülmesi gereken bir toplumun üyesi olduğunu geçmişine ihanet etmemesi gerektiğini yeni kuşağa anlatarak bireyi milliyetçi ideolojinin çizdiği sınırların içinde tutar. Smith (1986, pp. 66) mitler, efsaneler ve kahramanlık destanlarının uzun vadede zayıflayan dayanışma duygusunu güçlendirdiğini söyleyerek bu anlatıların milliyetçi ideolojiler için vazgeçilmezliğinin altını çizmektedir.

Kitle iletişim araçları; radyo, televizyon, gazete, sinema ve son dönemde sosyal medya, toplum adına ve toplum için gündem belirleme ve alg1 oluşturma görevini en etkili şekilde gerçekleştirmektedirler. Günümüzde artık filmlerin mitolojiler ürettiği rahatlıkla görülmektedir (Erdoğan ve Solmaz, 2005, s.37). Kültürel ürünlerin yaratıcısı ve aktarıcısı olan filmler bir yandan çağdaş mitler yaratırken diğer yandan gerçekliği yeniden kurarak egemen değerleri de yeniden üretmektedir (Gültekin, 2006, s.35). Sinema bu yanıyla, 'popüler milliyetçi ideolojinin yenidenüretim sürecinde en az devlet kadar etkilidir' (Güney, 2006, s.224).

Türk sinemasında son yıllarda milliyetçi filmlerde sayısal olarak artış gözlenmektedir. Bu çalışmada sinemada milliyetçi söylemin nasıl inşa edildiği ve sinemasal estetik ögelerin nasıl kullanıldığına bakılacaktır. Bu amaçla hem dünya hem de Türk tarihi için oldukça önemli bir tarihsel olayı ele alan Fetih 1453 filmi, göstergebilimsel yöntemle incelenecektir. Gündelik hayatta bireyin karşılaştığı olayları nasıl anlamlandırdığını 
çözmeye çalışan göstergebilim (Barthes, 1979), görüntülerle hikaye anlatma sanatı olan sinemanın kodlarını çözmek için en uygun yöntemlerden birisidir.

\section{Millet ve Milliyetçilik}

İngilizce karşıllı̆̆1 'nation' olan 'millet' sözcüğünün, Latince doğmak anlamına gelen 'nasci' kökünden türediğini ifade eden Heywood (2006, pp. 152), ulusun (nation) kültürel, siyasal ve psikolojik faktörlerin bir toplamı tarafından şekillendirilen kompleks bir olgu olduğundan bahseder. Arapça bir sözcük olan 'millet' kavramı, zaman içinde çeşitli dönüşümlere uğrayarak bugünkü yaygın bilinen anlamına kavuşmuştur. Millet; din, mezhep ya da aynı din veya aynı mezhebe mensup insanlar topluluğunu tanımlamaktadır (Ataman 1977, s.67).

Literatürde 'millet ve milliyetçilik' kavramları üzerine öncü araştırmalarıyla dikkat çeken Kedourie (1971, s.5), milletin konuşma dilinde, bir aileden büyük, kabile ve kavimden küçük bir topluluğu; doğuştan benzerlik gösteren bir insan kümesini ifade ettiğini yazmaktadır. Millet kavramına farklı bir bakış açısıyla yaklaşan Anderson (1993, s.21) milleti, 'hayal edilmiş cemaatler'2 olarak tanımlar. Ona göre, yüz yüze temasın geçerli olduğu ilkel köyler dişında bütün cemaatler ‘hayal edilmiş’tir.

Millet; ister hayal edilmiş, ister kurgulanmış, isterse kendiliğinden meydana gelmiş bir olgu olarak tanımlansın; milliyetçi ideoloji tarafından ulus-devletin temel yapı taşı olarak varlığına sürekli ihtiyaç duyulmaktadır. Bireyin bir millete mensup olma hissinin nasıl geliştiği, ya da kendisini neden bir millete ait hissetmek zorunda olduğu ancak milliyetçilik düşüncesi ile açılanabilir.

Milliyetçilik, modern toplumlardaki bireyler üzerinde güçlü etkileri olan, son iki yüz yıldır sosyalizm, komünizm, marksizm, demokrasi ve küreselleşme gibi birçok düşünce sistemlerini (az ya da çok) etkileyen, hatta bu düşünce sistemlerine kimi zaman baskın gelen (Baradat, 2012, s.62) bir olgu olarak ele alınmaktadır. Sosyal ve siyasal alanda etkisi bu

\footnotetext{
2 'Ulus, Hayal Edilmiş Bir Siyasal Topluluktur. Hayal Edilmiştir, Çünkü En Küçük Ulusun Üyeleri Bile Diğer Üyeleri Tanımayacak, Onlarla Tanışmayacak, Çoğu Hakkında Hiçbir Şey Işitmeyecektir Ama Yine De Her Birinin Zihninde Toplamlarının Hayali Yaşamaya Devam Eder' (Anderson, 1993, s.20).
} 
denli güçlü olan milliyetçilik, tek bir perspektifle açıklanamayacak kadar çok derin bir retoriği içinde barındırmaktadır (Calhoun, 2007, s.11).

Yeryüzünde yüzlerce ulusun olmasının, insanlığın uluslara bölünmesinin; bireyin kendine benzer bir kültürü, geçmişi ve yaşam biçimini paylaşan insanlarla bir araya gelmesinin, doğal yakınlaşma eğiliminden başka bir şeyi ifade etmediğini söyleyen Heywood (2006, pp. 154), milliyetçiliğe kültürel bir olgu olarak bakılması gerektiğini vurgulamaktadır. Türk tarihçisi Kaplan (1977, s.11), milliyetçiliğin kültür aracilığıyla aktarılan 'benlik şuuru'ndan başka bir şey olmadığını söylerken, aslında kavramın kültürel yönüne işaret etmektedir³.

Türk milliyetçiliğinin doğuşu ve tarihsel gelişimi üzerine yazılmış pek çok kaynağın da işaret ettiği gibi (Candan, 2006, Kafesoğlu, 2010, Köseoğlu, 2003, Roux, 2007) 'Türk milliyetçiliği' Osmanlı İmparatorluğu'nun son döneminde etkili olan düşünce akımlarından yalnızca birisidir ve üstelik kronolojik olarak en son ortaya çıkmıştır. Türklük düşüncesinin yeniden gündeme gelmesi ve aydınlar arasında Türkçülük siyasetinin bir çare olarak kabul edilmesinde özellikle Ziya Gökalp ve Yusuf Akçura'nın fikirleri etkili olmuştur.

Milliyetçi ideoloji, dil, din ve tarih argümanlarını kullanarak Türk kültürünün diğer kültürlerden üstün olduğu düşünesini yaymakta ve toplumsal birliği sağlamaya çalışmaktadır. Medeniyetin kaynağının Türklüğe özgülenmesi ve en eski kültür sahiplerinin Türkler olduğu inanc1 ve medeniyetin aslında Türklügün ruhunda zaten var olduğu ön kabulünü de beraberinde getirmektedir.

\section{Sinemada Estetiği Oluşturan Öğeler}

Sinema toplumsal bir olgu olarak, deneyimleri zenginleştirmenin ve paylaşmanın önemli bir yoludur. İnsanlara yalnız eğlence değil, düşünce

\footnotetext{
3 'Kültürel Milliyetçilik, Ulusun Soyut Bir Siyasal Topluluktan Ziyade Ayrı Bir Medeniyet Olarak Yeniden Yaratılmasına Birincil Vurgu Yapan Bir Milliyetçilik Türüdür. Kültürel Milliyetçiler, Devleti, Genellikle, Yabancı Değilse Bile Çevresel Bir Varlık Olarak Görürler. Siyasal Milliyetçilik 'Rasyonel' Ve Genellikle Ilkeli Iken, Kültürel Milliyetçilik Kendi 'Ruhu' lle Harekete Geçirilen Eşsiz, Tarihsel Ve Organik Bir Bütün Olarak Gördügü̈ Ulusa Romantik Bir Inanç Beslemesi Anlamında 'Mistik'tir. Karakter Olarak Sıklıkla Modern Karşıtı Olmakla Birlikte Kültürel Milliyetçilik Aynı Zamanda Halkın Kendisini 'Yeniden Yaratmasını' Mümkün Kılarak Bir Modernleşme Aracı Da Olabilir' (Heywood, 2006, Pp. 155).
} 
de sağlayan bu büyülü perdenin, toplumsal değişmelere yön verme gücü oldukça yüksektir. Film içeriklerinin değişmesi, toplumun geniş bir kesiminin değer yargıları, inançları, bakış açılarının da değiştiğini göstermektedir (Güçhan, 1992, s.70-71).

Modern bir hikâye anlatma aracı olan sinema, bu anlamıla bir düş makinesidir. Düşler yolculuğunda özellikle tiyatro, edebiyat, resim, fotoğraf, müzik, mimari vs. gibi alan ve türlerden beslenen sinema; doğrudan insanın duygularına seslenmesinin yanında, özel bir gösterim ortamında (tıpkı bir düş görür gibi) seyircisiyle buluşması, onu, insan için vazgeçilmez ve üstün k1lmaktadır (Yalsızuçanlar, 2010, s.367).

Sinema bir eğlence aracından çok bir hikaye anlatma aracıdır. Filmde anlatılmak istenenin ne olduğu ve öykünün hangi yöntemlerle anlatıldığının belirlenmesi film çözümlemelerinde önemlidir. Sinema anlatısının temelleri görüntü, 1şık, ses ve kurgu üzerine kurulmuştur ve filmin öyküsü tüm bunların bileşiminden meydana gelmektedir (Erdoğan ve Solmaz, 2005, s.33). Özön (1985, s.12) sinema anlatısının öğelerini görüntünün öğeleri olarak adlandırmektadır. Çerçeveleme, görüntü düzenlemesi, görüş noktası, kamera açısı, çekim ölçeği, oyuncunun oyunu, çevre-dekor, donatım-giysi-makyaj, aydınlatma, içerik-izlekkonu-oyunluk dramatik yapı, devinim, ses, renkler ve film yönetmeninin yetkinliğini sinemanın temel öğeleri arasında saymaktadır. Bu araştırmada Nijat Özön'ün ortaya koyduğu bu temel kavramlar (kamera, aydınlatma, ses ve kurgu) dikkate alınmış filmler bu kavramlar üzerinden değerlendirilmiştir.

\section{Kamera}

Sinemanın temel malzemesi olan görüntünün anlatıma etkisi; görüntü teknolojisindeki optik, mekanik, kimyasal ve elektronik gelişmelerin toplamı ve birbirleriyle etkileşimiyle mümkündür. Sinemada gösterilen şeyden çok onun gösterilme biçimi daha da önemlidir. Eisenstein (1984, s.17) sinemayı 'tüm sanatların en uluslararası olanı' diye tanımlarken, bunun sebebini de anlatım tekniklerinde gelinen yaratıcı uygulamalar olduğunu söylemektedir.

Yönetmen kameranın sağladığı olanaklarla, bir insanı olduğundan büyük ya da küçük, güzel ya da çirkin gösterebilir. Oyuncunun nereden, 
hangi açıyla ve hangi objektifle çekildiğine bağlı olarak izleyici, oyuncunun güçlü ya da güçsüz olduğuna kanaat getirecektir (Büker, 1991, s.49). Bir şeyi olduğundan farklı gösterebilme, objektif seçimi ve kameranın konumu ile doğrudan ilişkilidir. Balazs'a (1968, s.307) göre, sinemanın sanat olarak kabul edilmesi kameranın yerinin değiştirilebilir olmasıyla mümkün olmuştur. Ona göre, "eğer kamera sabit kalsaydı, sinema mekanik bir kopyacılıktan" öteye geçemeyecek, sıradan bir kayıt aracı olarak tarihteki yerini alacaktı.

Barbaro (1968, s.350), Özgür Ve Özerk Bir Yaratma adlı makalesinde; kamera, 1ş1k, ses, kurgu vb. mekanik olanaklara muhtaç olan sinemanın sanat olarak değerlendirilemeyeceği yönündeki tartışmalara değinir. Film yapımı için gerekli olan bu aygıtların, salt bir makine olarak ele alınmasının eksik bir bakış olduğunu dile getiren Barbaro, kameranın başka herhangi bir makine ile karşılaştırılamayacağını ısrarla vurgular" Tüm filmsel hareketler; görüntü geçişleri, kamera hareketleri, kamera açısı, objektifin özelliği ve kameranın yapabileceği daha birçok şey, anlatıya hizmet etmek için kullanılması gerektiğinin altı çizilir.

\section{Aydinlatma}

Görme olayının gerçekleşmesi için vazgeçilmez olan 1şık, yaşamın temel öğelerindendir. İnsan için ş̧ık, nesneleri algılamak ve anlamlandırmak için gereklidir. Tüm kültürlerde bilgeliğin ve iyiliğin sembolü olan 1şık; Türk kültüründe karanlığın, bilgisizliğin ve cehaletin karşıtı olarak kodlanmıştır. Ne kadar gizli olursa olsun ışık, gerçeği aydınlatmada insan aklın temsil etmektedir.

İnsanoğlunun 1şık ve gölge ile olan ilişkisi yüzyıllar öncesine dayanmaktadır. İnsanın dış dünyayı algılamasında ışığın ne kadar önemli olduğunu Platon Devlet adlı kitabında örnekleyerek açıklamaktadır. Pla-

\footnotetext{
${ }^{4}$ Sıradan Bir Makinadan Beklenen Verilen Koordinatlara Uymasıdır. Örneğin Bir Fotokopi Makinası, Istenildiği Kadar Kopya Yapmakla Yükümlüdür Ve Her Bir Kopyası Bir Diğeriyle Aynıdır. Makine Bu Süreçte Hiçbir Yardıma Ve Desteğe Muhtaç Olmadan Bu Işlemi Yapabilmektedir. Fakat Kameranın Çalışma Prensibi Çok Farklıdır. Onun Görüntü Kaydedebilmesi Için Insanın Bilgisine, Aklına Ve En Önemlisi Bakış Açısına Ihtiyacı Vardır. Böyle Olduğu Içindir Ki, Aynı Kamerayla Farklı Yönetmenlerin Çektikleri Kareler Birbirinden Çok Farklıdır (Barbaro, 1968, s.350).
} 
ton, karanlık bir mağaradan içeri sızan 1şığın etkisiyle mağara duvarlarında oluşan gölgeleri ve bu ışık ve gölgelerin mağaranın içindeki insanları nasıl etkilediğini anlatmaktadır.

Yukarı dünyayı görmek isterlerse, buna alı̧ması gerekir. Rahatça görebildiği ilk şeyler gölgeler olacak. Sonra, insanlarm ve nesnelerin sudaki yansiları, sonra da kendileri. Daha sonra da, gözlerini yukarı kaldırıp, güneşten önce yıldızları, ayı, gökyüzünü seyredecek. En sonunda da, güneşi; ama artık sularda, ya da başka şeylerdeki yansılarıyla değil, olduğu yerde, olduğu gibi... İste ancak o zaman anlayabilir ki, mevsimleri, yıllar yapan güneştir. Bütün görünen dünyayı güneş düzenler. Mağarada onun ve arkadaşlarının gördükleri her şeyin asıl kaynağı güneştir (Platon, 2008, s.33).

Sadece insanın fiziksel dünyasını değil, ruhsal ve bilişsel dünyasını da aydınlatan, ufkunu açan ışığın etkilerini Platon hikâyesinde uzun uzun anlatmaktadır. Platon'un bu hikâyesi, Platon'dan yaklaşık 2000 yıl sonra gerçekleşen aydınlatma tekniğinin kuramsal zeminini oluşturduğu söylenebilir.

\section{Ses}

Günlük yaşamın ayrılmaz bir parçası haline gelen ses, yaşamın büyük bir kısmını işgal etmektedir. Ses yaşamla o kadar iç içe geçmiştir ki, çoğu zaman varlığ1 bile fark edilemez. Sözen (2003, s.32), Sinemada Ses ve Kullanım kitabında insanın sesleri algilayabilmesinde sesin yapisal ve teknik unsurlarının yanında (sesin frekans düzeyi, sesin tonu vs.) psikolojik ve sosyal faktörlerin de önemli rolü olduğundan bahseder. Örneğin, keyifli ya da keyifsiz olmak, yorgun ya da dinlenmiş olmak, yaşlı ve genç olmak gibi bir dizi faktör kişinin sesi algılamasını doğrudan etkilemektedir. Issız bir adada tek başına yaşayan insan, doğadaki diğer canlı ve cansız nesnelerle ses ile iletişim kurmaktadır. Bu anlamda ses, yaşamsal öneme sahiptir ve sinemayı gerçeğe daha çok yaklaştırmaktadır. Anlatısını hayattan kesitler sunarak kuran sinema için de ses vazgeçilmez bir öğe olarak kabul edilmektedir (Özön, 1972, s.109). 
Sinema sadece görüntülerden ibaret bir sanat değildir. Görüntü gibi ses de filmin temel öğesidir (Can ve Esen, 2008, s.160). Görsel-işitsel bir sanat olan sinemada ses, hem görüntüdeki anlamları güçlendiren dramatik bir öğe, hem de başlı başına bir anlatım aracı olarak var olmaktadır. Kendine özgü bir duygu durumu yaratma gücüne sahip olan ses; özellikle görüntüyle bütünleştiğinde izleyicinin algısını yönlendiren güçlü bir silaha dönüşmektedir (Bordwell ve Thompson, 2008, s.265).

Sinemada sesin kullanımı, film gösterimlerine müziğin eşlik etmesiyle başlamıştır. Bu anlamda ilk film müziği; 28 Aralık 1895 günü sinema tarihinin ilk gösterimi sırasında solo piyanonun gösterime eşlik etmesiyle başladığı bilinmektedir. Sinemanın ilk yıllarında film gösterimlerine eşlik eden piyano ve kemanın yerini, kısa bir zaman sonra orkestralar almıştır (Thompson ve Bordwell, 2003, s.193) . Bu dönemde filmler sessiz olsa da, gösterimler müzik eşliğinde yapılmakta; ses, sinemanın icadıyla eş zamanlı olarak filmlerdeki yerini almaktadır.

Sessiz sinemanın tarihsel gelişimini tamamlayarak yerini sesli filmlere bırakmasıyla, sinema tarihinde yeni bir dönem başlamıştır. Ses, sinemanın hem yapım tekniklerini hem de sanatsal anlayışını tersyüz etmiştir. Örneğin, sesli filmlerle birlikte yeniden seslendirme (dublaj) sektörü doğmuştur. Filmlerin uluslararası çapta dolaşıma girebilmesi için, gösterimin yapılacağı ülkenin diline göre filmin yeniden seslendirme gerekliliği, sinemanın önemli bir kolunu teşkil etmektedir (Sözen, 2003, s.158159).

\section{Kurgu}

Kurgu dışında sinemanın öğeleri arasında sayılan her şey, diğer sanat dallarından ödünç alınmış ya da sinemaya uyarlanmıştır. Öykü, oyunculuk, ses ve müzik uygarlık tarihi kadar eski sanatlardandır. Dmytryk'e (2007, s.102) göre, sinemanın yedinci sanat olduğunun en büyük göstergesi 'kurgu'dur. Kurgu sinemayı, tiyatronun ve onun geleneğinden kurtarmıştır. Tiyatro, zaman ve mekân birlikteliğini zorunlu kılarken, sinema her ikisine de bağımlı olmayarak, farklı zaman ve mekânda çekilen

\footnotetext{
${ }^{5}$ Sinema Tarihinin Ilk Gösteriminden Çok Kısa Bir Zaman Sonra, Lumière Kardeşler 20 Şubat 1896 Tarihinde Londra'nın Çeşitli Tiyatrolarında Filmlerini Orkestra Eşliğinde Göstermeye Başlamışlardır (Erdoğan Ve Solmaz, 2005, s.75).
} 
görüntülerin kurgulanması sayesinde kendine özgü bir anlatım dili olduğunu ispat etmiştir.

Arnheim (2002, s.87-88), kurgunun 'sinema sanatına giden asil bir yol' olduğunu; insan emeğine ve zihni beceriye dayanan bir eylem olmasından ötürü eksikliklerinin olduğunu, bu eksiklerin kurguyu değerli kıldığını ve sinemayı sanat dalı haline getirdiğini söylemektedir. "Bir kişi tarafından kontrol edilen kayıt sürecinin sonunda ortaya çıkan, yüzeysel addedilen tek bir görüntü, unutulmamalıdır ki, doğanın taklidinden başka bir şey değildir. Ne var ki iş montaja geldiğinde, bu sürece insan eli değer; zaman kırılır, zaman-mekân düzeninde birbirinden koparılan şeyler tekrar bir araya getirilir. $\mathrm{Bu}$ çok daha gerçek bir yaratıcılığa ve biçimlendirici işlevselliğe işaret eder" (Arnheim, 2002, s.87-88).

Sinema tarihinde ilk kurgu uygulamalarını Amerikalı yönetmen Grifith'in yaptığı bilinse de kurguyu özel bir sanat biçimi olarak geliştirenler Eisenstein, Pudovkin, Vertov, Kuleşov ve diğer Rus sinemacılardır. Dmytryk (2007, s.102), sessiz filmin son yıllarında Sovyet sinema sanatçılarının kurgu tekniğini üst düzey bir sanat haline getirdiklerini söylemektedir.

Sinemada kurgu, birbirinden bağımsız iki çekimin yan yana getirilerek yeni bir anlamın oluşmasını sağlar. Sovyetler Birliği döneminin sinemacıları Eisenstein, Kuleşov ve Pudovkin, kurgunun insan algısı üzerindeki etkilerini araştıran isimler olmuşlardır. Sovyet sinemacilara göre kurgu yaratıcı güçtür.

Kurgu, filmin anlamını oluştururken izleyicinin de anlamı çözümleme noktasında filme dâhil olmasını istemektedir. Eisenstein Potemkin Zırhlısı filminde uyuyan, uyanan, doğrulan aslan heykellerinin birbiri ardına kurgulanmaları, kükreyen ve başkaldıran bir aslanı çağrıştırmaktadır (Özön, 1984, s.LVIII). İzleyiciyi yaratma sürecine dâhil ettiğinden dolayı kurgunun sinemasal anlatımdaki yeri önemlidir (Eisenstein, 1984, s.43). Bu yönüyle kurgunun anlatımı doğrudan etkileyen bir yanı olduğu gibi, seyircinin de anlatıma kurgu yoluyla katıldığı bir yapı söz konusudur.

\section{Yöntem ve Amaç}

$\mathrm{Bu}$ araştırmanın temel amacı; Türk sinemasında milliyetçiliğin inşasında sinemanın estetik unsurlarının nasıl kullanıldığını, bu unsurların anlatımı 
güçlendirmedeki rollerinin neler olduğunu tespit etmektir. Milliyetçi ideoloji tarihte yaşanılan olayları gelecek kuşaklara anlatarak milliyetçi düşüncenin devamını hedefler. Türk tarihi için çok önemli olan İstanbul'un fethini konu alan Fetih 1453 filmi, milliyetçi söylemin en yoğun kullanıldığ1 filmlerdendir. Bu çalışmada Fetih 1453 filminin milliyetçi söylemi nasıl inşa ettiği ve bunu yaparken sinemanın estetik öğelerini nasıl kullandığına bakılacaktır. Film göstergebilimsel yöntemin ortaya koyduğu metodoloji ile analiz edilmeye ve çalışılacaktır.

İletişimin göstergeler aracılığıyla kurulduğu düşüncesinden hareketle pek çok düşünür ve bilim insanının göstergelerin anlamları üzerine yürüttükleri çalışmalar, göstergebilimin temellerinin çok eskilere dayandığını ortaya koymaktadır. Rifat, (2009, s.27). Göstergebilimin Abc'si isimli kitabında, gösterge kavramı üstüne Eski Çağ'dan günümüze birçok felsefeci, bilim insanı ve özellikle hekimin düşünce ürettiğini, başta dilsel göstergeler olmak üzere çeşitli alanlardaki göstergeleri, belirtileri incelediklerini söylemektedir.

Çağdaş göstergebilimin kuruluş temelleri; 20.yy'ın başında Amerikalı filozof Charles Sanders Peirce (1839-1914) ve İsviçreli dilbilimci Ferdinand de Saussure (1857-1913)'ün neredeyse eşzamanlı olarak, birbirlerinden habersiz şekilde yaptıkları çalışmalarla atılmıştır. Felsefe, mantık ve matematik bilimi üzerine çalışmalar yapan Amerikalı Charles Sanders Peirce hem dilsel hem de dil dışı göstergelerle ilgili bir kuram tasarlamış ve buna 'semiotic' adını vermiştir. S. Peirce'e göre 'göstergelerin biçimsel öğretisi' olan göstergebilim, mantık'ın bir başka adıdır. Peirce'e göre bir gösterge, başka bir nesnenin yerine koyulabilme özelliğine ve kapasitesine sahip olan bir şeydir (Sebeok, 2000, s.270).

Modern dilbilimin tartışmasız kurucusu olarak kabul edilen İsviçreli dilbilimci Ferdinand de Saussure'ün göstergebilim üzerine düşünceleri, 1913'te ölümünden sonra öğrencilerinin ders notlarından toparlanmış ve bu notlar Genel Dil Bilim Dersleri (Cours de Linguistique Genérale) adiyla kitap olarak yayımlanmıştır (Saussure, 1976). Saussure, göstergebilimi (semiology), 'göstergelerin toplum yaşamı içindeki durumunu' inceleyen bir bilim dalı olarak tanımlamıştır (Atabek, 2007, s.67). 'Dil'in düşünceleri ifade eden bir göstergeler sistemi olduğunu vurgulayan Saussure, göstergebilimi tanımlarken üç temel kavramdan da söz eder. Bunlar; 'gösterge', 'gösteren' ve 'gösterilen' kavramlarıdır. 'Gösterge' görüntü ve 
nesneyi, 'gösteren'; göstergenin fiziki boyutunu, 'gösterilen' ise göstergenin kavramsal boyutunu açklar (Parsa ve Parsa, 2002, s.8).

Peirce'ün göstergelerin mantıksal işlevini vurgulamasına karşın, Saussure göstergelerin toplumsal işlevi üzerinde durmuştur. Kendisi de mantıkçı olan Peirce mantıksal kökenli bir göstergebilimin temelini atarken, toplumsal olan ile ruhsal olanı aynı kuram içinde birleştirmeye çalışan Saussure daha çok dilbilim üzerine yoğunlaşmış, dil dışı göstergeler üzerine çalışmalar yapılması gerektiğini söylemiştir (Rifat, 2009, s.33).

Barthes'in göstergebilim kuramına getirdiği düzanlam ve yananlam kavramları, metnin farklı boyutlardan okunmasını sağlar. Barthes'a göre (1979), düzanlam göstergenin neyi temsil ettiğini ortaya koyarken, yananlam göstergenin nasıl temsil edildiği ile ilgilenmektedir. Düzanlam, kameranın doğrultulduğu nesnenin film üzerinde mekanik bir şekilde yeniden üretimidir. Yananlam ise bu sürecin insani boyutudur: çerçeveleme, objektif, odak uzunluğu, ışık, kamera açısı, film kalitesi vb. seçimidir. Düzanlam neyin görüntülendiği, yananlam ise nasıl görüntülendiğidir (Fiske, 1996, s.117).

Sinema, göstergelerin en yoğun kullanıldığı sanat dallarından birisi ve belki de en önemlisidir. Sinemada yapay bir mekân içinde kullanılan nesneler, dekor, olayın geçtiği zaman ve mekânı belirten değişik göstergeler, 1şık, aksesuar ve mobilyayı belirten göstergeler söz konusudur. Sahnede nesnelerin düzenlenmesi, oyuncuların sahne üzerindeki konumları, ışık ve rengin kullanımı, anlamın meydana getirilmesinde çok büyük öneme sahiptirler (Akdoğan, 2001, s.234). Sinema anlatısının temelleri; görüntü, 1şık, ses ve kurgu üzerine kurulmuştur (Erdoğan, Solmaz, 2005, s.33).

Metz, sinemanın en küçük birimi olan çekimi sözcüğe değil, tümceye benzetmektedir. Örneğin, bir tabanca görüntüsü, bir sinema tümcesinin öznesi ya da nesnesi değil, bizzat tümcenin kendisidir. "İşte tabanca!" ifadesindeki gibi bir iddiadır. Çekim, tümce gibi kesin ve açık anlatımlıdır. Sözcükler, sözlüklerde hazır bulunabilir, ancak tümcelerin ve çekimlerin aranabileceği sözlükler yoktur (Andrew, 2010, s.328). 


\section{Fetih 1453 (Yönetmen: Fatih Aksoy / 2012)}

İstanbul'un fetih hikayesini beyaz perdeye taşıyan Fetih 1453, Türk Sinemasında bir takım yenilikleri barındırmaktadır. Görüntü kayıt teknolojilerinden bilgisayar destekli video kurgu teknolojisine, kostümlerden makyajın etkili ve etkin kullanımına ve gerçek mekanlardan çekim platolarına kadar bir çok açıdan yeniliklerle dolu bir filmdir. Sadece Osmanlı içinde değil, tüm dünya Türkleri ve Müslümanları için de oldukça önemli olan bir olayı beyaz perdeye taşıyan yönetmen, milliyetçi söylemi inşa ederken sinemanın estetik öğelerinden yararlanmıştır.

Avrupa ve Asya kıtalarını birbirine bağlayan İstanbul'un alınması, iki kıta üzerinde yayılmakta olan Osmanlı Devleti'nin kök salabilmesi ve daha da güçlenmesi için gerekliydi. Sultan II. Mehmet, boğazlara tamamıla egemen olmadıkça devleti "Cihan Devleti" yapamayacağının farkındaydı. Hz. Muhammed (sav)'in "İstanbul muhakkak feth olunacaktır. Onu fetheden komutan ne güzel komutan ve onun askeri ne güzel askerdir" (hadis.. kaynak) sözünü çok iyi bilen Sultan Mehmet'in İstanbul'u almak için güçlü motivasyonları vardı.

\section{Öykü}

Babası II. Murat'ın ölüm haberini Saruhan Sancağı'ndayken alan Sultan Mehmet, tahta oturduğunda hiç vakit kaybetmeden Osmanlı Devleti'ni bir Cihan Devleti yapmak için çalışmalara başlar. Hz. Muhammed'in sözünden ilham alan Sultan Mehmet'in en büyük amacı İstanbul'u fethetmektir.

Bu sırada Doğu Roma İmparatoru Konstantin, genç yaşından dolayı toy ve basiretsiz olduğunu düşündüğü Sultan Mehmet'e karşı elinde tutsak olan Şehzade Orhan'ı kullanarak ağır tahsisatlar talebinde bulunur. İmparatorun asıl amacı, genç padişahı halkı önünde itibarsızlaştırmaktır. Sultan Mehmet önce İmparator Konstantin'e bir elçi göndererek, Orhan için ödediği tahsisatı artık yollamayacağını bildirir; ardından Anadolu Hisarı'nın karşısında Boğazkesen (Rumeli) Hisarı'nın yapımına başlar. Bir ayı aşkın bir süredir devam eden kuşatmada surları aşamayan Sultan Mehmet, güçlü surları aşabilecek büyüklükte toplar döktürerek ve gemileri karadan yürüterek İstanbul'u fetheder. 


\section{Filmdeki Milliyetçi Söylemler}

Filmde geniş okumalara imkân veren semboller/gösterenler (kuş, tespih, yüzük, harita, sancak vb.) birebir işaret ettikleri anlamlardan bazen daha çoğuna karşılık gelmektedir. Film boyunca sık sık karşımıza çıkan başta Hazreti Muhammet'in hadisi, Fetih Suresi, Eyyüp el-Ensari'nin Mezarı ve yüzük gibi semboller, Osmanlı Devleti'ni ve dolayısıyla tebaayı köklü bir tarihsel arka plana bağlamaktadır.

Filmde kuş simgesini kullanan yönetmen, kuşu haber alma, bir haberi bir yerden başka bir yere taşımak için kullanmıştır. Ebu Eyyüp hadisi bitirir bitirmez Medine semalarında uçmaya başlayan kuş, adeta bir haberci gibi çöller aşıp bu kutlu haberi Osmanlı topraklarına kadar ulaştırmaktadır. Böylece Arabistan yarım adasından başlayan hikâye Anadolu'ya 50 yıl sonrasına taşınmıştır. ${ }^{6}$ Kamerasıyla kuşu takip eden yönetmen, zamansal ve mekânsal değişikliği seyircisine anlatmakta zorlanmamıştır.

Sarayında oğlu Mehmet'in doğum haberini bekleyen Sultan II. Murat, Fetih suresini okumaktadır. Yönetmen filmin hikâyesinin doğrudan İstanbul'un fethi ile ilgili olmasından dolayı, sahnede okunması için Fetih suresinden ayetleri tercih etmiştir.

İmparatorun sarayı ve odasındaki hemen hemen her şeyin (oturulan koltuğun, su içilen bardağın, giyilen elbiseleri) normal boyutlardan daha büyük olması, imparatorun kudretinin büyüklüğünün göstergesidir.

Filmde babadan oğula hatıra olarak kalan tek somut simge tespihtir. Babasının vefatının ardından Sultan Mehmet'i devletin geleneklerine bağlayan; ölmüş olan babasına cihan devleti kurma sözü verdiğinde de Sultan Mehmet'e sözünü hatırlatan tek simge yine tespihtir. Aylar süren kuşatmaya rağmen surları aşamayan Sultan Mehmet, umudunu yitirdiği anlarda kuşağında sakladığı tespihi çıkartıp öperek rahatlar, kendini motive eder ve güç kazanır.

İktidarın en büyük göstergelerinden birisi de yüzüktür. Özellikle nesilden nesile aktarılan yüzükler köklü bir geleneği temsil etmektedirler. Yönetmenin Sultan Mehmet'in parmağındaki yüzüğe yaptığı yakın plan çekimler, bu düşünceyi pekiştirmektedir. Kuşatmanın uzamasından

\footnotetext{
${ }^{6}$ Medine Yıllarında Başlayan Hikaye (657), Edirne'ye 29 Mart 1432'ye Taşınmıştır.
} 
kaynaklı ruhsal olarak sıkıntılı günler yaşayan Sultan Mehmet, rüyasında Osmanlı Devleti'nin kurucusu Osman Bey'i görür. Osman Bey rüyasında “Bu yüzü̆̆̈̈ en çok hak eden sensin. Peygamberin müjdelediği o güzel kumandan sensin Mehmet. Gazan mübarek olsun" diyerek elindeki yüzüğü çıkartıp Sultan Mehmet'e uzatır. Sultan Mehmet tam yüzüğü alacakken yüzük kızgın ateşlerin ortasına düşer. Sahne sultan Mehmet'in kan ter içinde bağırarak uyanmasiyla son bulur.

Ortak değerlere sahip insanların bir arada olduğunun en önemli göstergesi bayraktır. Savaşlarda ise orduları birbirinden ayıran en temel gösterge sancaktır. Sancak tüm orduyu temsil etmesi bakımından önemlidir. Savaşta sancağın kaleye/hisara dikilmesi, fethin gerçekleştirildiği anlamına gelir.7 Bu sebeple sancağı taşıyan askerler düşman kuvvetlerin öncelikli hedefi arasında yer almaktadır. Böylesine önemli ve tehlikeli bir görevi de özel eğitilmiş askerler yapar. Filmde sancağı taşıyan Hüseyin'in vurulması anını özel efektlerle gösteren yönetmen, filmin müziği ve görüntünün hızı ile oynayarak seyircinin zaman algısını değiştirmektedir. Arkadaşının vurulmasından sonra sancağı yere düşürmeden alan Ulubatlı Hasan'da sancağı burçlara dikerken ok yağmuruna tutulur. Yönetmenin dramatik etkiyi artırmak için müziğini değiştirmesi ve görüntü hızını değiştirmesindeki amaç, sancağı dikmek uğruna canını defa eden Ulubatlı Hasan'ı kahramanlaştırmaktır.

Sultan Mehmet'in savaşa hazırlık sahnesi hem estetik hem de milliyetçi kodları içinde barındırması açısından oldukça önemlidir. Yakın çekimlerle zırhını giyerken görülen sultanın bu sekansı, ordunun savaşa hazırlık aşamasının tek tek gösterilmesinden daha etkilidir. Gerçekte Sultan'ın bu hazırlığı, başka diğer hazırlıkların tamamlandığı anlamına da gelmektedir. Sultanın yüzü kameraya dönük değildir. Sahnenin çekiminde kullanılan yakın planlar, yavaşlatılmış görüntüler ve müzik kullanımı, karakteri yücelten en önemli unsurlar arasında sayılabilir.

Filmde karakterlerin vücutlarına yapılan yakın çekimlerle erkek bedeni fetişleştirilmektedir. Başta Sultan Mehmet, Ulubatlı Hasan, Giustiniani ve lağımcılar olmak üzere birçok askerin vücutlarına yapılan yakın çekimlerde bunu görmek mümkündür. Özellikle Sultan Mehmet ile

\footnotetext{
7 Ulubatlı Hasan Ile Era'nın Vedalaşmalarında Ulubatlı Hasan'ın; 'Yarın Sancağımızı Dikeceğiz, Göreceksin Bak Başaracağız' Demesi Sancağın Dikilmesinin Zafer Anlamına Geldiğini Bir Kere Daha Hatırlatmaktadır.
} 
Ulubatlı Hasan'ın kılıç talimi yaptıkları sahnede, karakterlerin üzerlerinin prodüksiyon tarafından ıslatılması, bedenin estetize edilmesine iyi bir örnektir.

Aylar süren kuşatmadan bir netice alamayan Sultan Mehmet, gemileri karadan yürütüp Haliç'e indirme kararı alır. Akla ve mantığa ters olsa da milletin geleceği için yapılması gereken ne varsa yapılmalı, milletin menfaati için tüm zorluklar aşılmalıdır. Zaten Sultan Mehmet böylesine kritik kararlar alabildiği için İstanbul'u fethetmiş, adının önüne Fatih eklenmiştir.

Sultan Mehmet, güncel siyaseti çok iyi okuyabilen bir padişahtır. Tahta çıktığı ilk günlerde İmparatorun barış siyasetiyle kendisini köşeye sıkıştırmak istediğini anlayan Sultan Mehmet, düşmanını kendi silahı ile vurmuş, barış siyasetini etkin kullanarak düşmanının bir adım önüne geçmiştir. Rumeli Hisarı yapımından rahatsız olan Avrupalı devletlerin karşısında dimdik durarak kararlılığıyla büyük kazanımlar elde etmiştir. "Papa haçlı ordusu mu toplayacakmıs? Elinden geleni ardına koymasın. Varna'da, Kosova'da nasıl tepelediysek yine hadlerini bildiririz. Ben, benden önceli sultanlara benzemem. Ben Sultan Mehmet Han'ım. Mülküm olan Rumeli' de hisar yapmak istersem yaparım. Topraklarımda olan her şey benim kudretim altındadır" diyerek farklı bir padişah olduğunun altını çizmektedir.

Günler süren kuşatmadan bir sonuç alamayan Sultan Mehmet, çaresizlik içinde kıvranmakta ve bir çıkış yolu arar. Filmin dönüm noktası Akşemsettin ile Sultan Mehmet görüştüğü sahnedir. Akşemsettin'in filme dâhil edilmesiyle birlikte hikâye yeniden Hz. Muhammed (s.a.v)'e ve peygamberin arkadaşlarından Ebu Eyyüp El-Ensari'ye bağlanır.

Akşemsettin, öğrencisi Sultan Mehmet'e rüyasını anlatır:

Buraya gelmeden evvel üç gün istihareye yattım Mehmet. Bu kuşatma hayra vesile mi değil mi diye. Hamt olsun son gece muradım hâsıl oldu. Ebu Eyyüb El-Ensar'i hazretleri rüyama teşrif ettiler. Bana mezarmm yerini bildirdi. Git dedi. Mehmet'e göster. Neden surlara çok yakın yattığımı anlat. 
Aksemsettin'in tarifi doğrultusuna yapılan kazıda Ebu Eyyüp El-Ensari'nin mezarı bulunur ${ }^{8}$. Milliyetçi ideoloji kendi kökünü tarihin derinliklerinde arayarak, geleceğini sağlam temeller üstüne inşa etmek istemektedir.

Sultan Mehmet aylar süren kuşatma sonuç vermeyince, son taarruzdan önce askerlerine bir konuşma yapar. Sultan'ın bu konuşması milliyetçi ideolojinin tüm kodlarını içinde barındırmaktadır. Konuşmasında geçmişteki başarıları örnek gösteren Sultan Fatih, askerlerinden inançla yeni bir başarıya hep birlikte imza atmalarını ister.

Askerlerim. Geçmişimiz zaferlerle dolu. Nice zorlu kaleleri, şehirleri aldık. Sarp dağları aştık. Düşmanların bizi yok etmek için göğsümüze uzattı̆̆ı kılıçlarım kırdık. Kibirle sallanan bayraklarını alaşağı ettik. Gaza uğruna can verip mihnete katlandık. Bu gün burada bize düşen ceddimize layık olduğumuz askerler olduğumuzu göstermektir. Unutmayın! Büyük fetihler inançla yapılır. Cesaretimizle bu surları aşacağımızı biliyorum. Sabah olduğunda hiçbir kulun uyanmadı̆̆̆ kutlu bir güne açacağız gözlerimizi. Düşmanı dize getirmeden şehadet şerbetini içmeyeceğiz. Allah-ü Ekber

29 Mayıs günü Sultan Mehmet, arkasında saf tutan milyonlarca askere sabah namazını kıldırır. Tüm askerlerin Sultanın arkasında saf tutarak birlikte namaz kılmaları, çok güçlü bir göstergedir. Omuz omuza saf tutan milyonlarca asker artık 'hal' diliyle İstanbul'u istediklerini ve Allah'tan yardım beklediklerini anlatmaktadırlar. Sahnedeki büyüleyici kalabalık, rükû ve secdeye giderken onlarca askerin eş zamanlı hareketleri ve bu eş zamanlı hareketler sonucu duyulan sesler (secdeye giden askerlerin dizlerinin toprağa değmesi vs.), ordunun kararlılığını ve inanmışlığının işaretidir.

Müzik eşliğinde bayrağın rüzgârda dalgalanması Fetih'in gerçekleştiği anlamına gelir. Sultan Mehmet surlardan içeriye girdiğinde halkın ‘sul-

\footnotetext{
${ }^{8}$ Eyyüp El- Ensari Hazretleri, Hz. Muhammed'in Müjdelediği Askerlerden Olabilmek Için İstanbul Sınırlarına Kadar Gelmiş, O Zaman Yapılan Kuşatmada Şehit Olmuş Bir Sahabedir.
} 
tanımız çok yaşa' nidalarıyla karşılanır. Ortodoks Hristiyanların saklandığı Ayasofya'ya giden Sultan Mehmet, Ayasofya'nın kapısından adeta kurtarıcı melek olarak girmiştir. Sultan kalabalığa yaklaşarak; "korkmayın. Bundan böyle canımız bir, malımız bir, kaderimiz birdir. İnancınızı dilediğiniz gibi yaşamakta serbestsiniz" der. Fatih'in konuşmasından sonra Ayasofya'ya sığınan endişeli yüzler gülmeye başlar. Sultan Mehmet, bir kız çocuğunu kucağına alarak onu sever. Kamera Ayasofya'nın kubbesine doğru yükselir ve perde kararır.

\section{Temel Anlamın Gösterenleri ve Filmin Estetiği}

\section{Kamera}

Filmin genelinde daha çok nesnel kamera kullanan yönetmen bazı sahnelerde, verilen mesajı güçlendirmek amaciyla kamerasını öznel olarak da kullanmıştır. Filmin ilk sekansında (Medine sekansı) şehirden kısa bir görüntünün ardından, Hz. Muhammed'in evinin içine kesme ile geçilir. Yönetmen bu sahnede kamerasını öznel kamera olarak kullanmış, kamera Hz. Muhammed'in gözü konumuna geçmiştir. Karşısında oturanları onayladığında kameranın aşağı yukarı yaptığı hafif hareket (bir davranışı onaylarken başın sallanması hareketi), Hz. Muhammed'in başını sallamasıyla özdeşleştirilmektedir. Bu sahnede kameranın öznel kamera olarak kullanımı, peygamberin varlığını seyirciye göstermeden anlatmanın en güzel örneğidir.

Ulubatlı Hasan elindeki sancağı kaleye dikmek için tepeye çıtığında da kamera öznel kullanılmıştır. Vücudu oklarla dolu olan ve artık dayanacak gücü kalmayan Ulubatlı Hasan'ın kalenin üstünden tüm savaş meydanına baktı̆̆ çekim öznel kamera ile çekilmiştir. Hasan'ın gözü konumunda olan kamera bulanık ve etrafı kan kırmızısı görmektedir.

Filmde kamera hareketlerinden kaydırma hareketini çok sık kullanan yönetmen, bu sayede sahneye dinamizm katmayı ve seyirciyi sahnenin içine çekmeyi amaçlamıştır. Sultan II. Murat'ın Kur'an okuduğu sahnede kamera sağa doğru (sultanı görene kadar) kayar. Sahnenin sonunda ise, kamera hiç kesme yapmadan ileriye doğru kaydırma yaparak sultan II. Murat'a iyice yaklaşır. 
Özellikle toplu namaz sahnesinde omuz omuza saf durmuş askerleri gösterirken kamerasını soldan sağa ve sağdan sola doğru kaydırarak kullanan yönetmen, hem saflar arasındaki mesafeyi hem de derinliği açığa çıkartmaktadır.

Filmdeki en etkili kaydırma hareketlerinden birisi de, savaş meydanında iki ordunun ilk kez karşı karşıya geldikleri sahnede, kameranın kaydırma hareketini kullanarak askerleri taramasıdır. Savaşın başlama emri de Sultan Mehmet tarafından bu sahnenin devamında verilmektedir. Kamera, boy planda askerlerinin yanında görülen Sultan Mehmet'e ileriye doğru aniden yaklaşır. Alt açı çekimde askerlerin arasından hızlıca Sultanın omuz planına kadar yaklaşan kamera, omuz planda durduğunda Sultan başıyla günlerce sürecek savaşın başlama işaretini verir.

Sultan Mehmet tahta ilk oturduğunda kamera Sultan'ı alt açıdan çekerek, görkem ve ihtişamı yansıtır. Sahne düzenlemesinde sadece Sultan yüksekte otururken, vezirler ayakta ve iki yana dizilmişlerdir. Sultanın vezirlerine bakışı üst açıdandır. Vezirler dâhil herkes padişaha ise alt açıdan bakar. Okçuların fırlattıkları oklar bir yağmur gibi gökyüzünden yağarken kameranın konumu alt açıdır. Kameranın alt açıdan binlerce okun gökyüzünden aşağıya doğru süzüldüğünü göstermesi, görüntünün estetik değerini artırmaktadır.

İstanbul'un kuşatması uzadıkça devletin ileri gelenleri arasında hararetli tartışmalar yaşanır. Sultanın çadırında yapılan bir toplantıda Halil Paşa ile Zağanos Paşa'nın tartışmasında yönetmen tartışmanın şiddetini seyirciye anlatmak için kamerayı hareketli kullanmayı tercih etmiştir. Zağanos Paşa'nın heyecanlı konuşmasına uygun olarak kameranın ön görülemeyen hareketleri seyirciyi de sahnenin heyecanı içine çekmektedir. Bu sahnede karakterlerin diyaloglarındaki sert ve keskin ifadeler kamera hareketlerine de yansımaktadır.

Kameranın durduğu yer sahnenin anlamını etkilemektedir. Buna en güzel örnek; Osmanlı Sultanı Mehmet'e ihanet ettiği anlaşıldığı için Karamanoğlu İbrahim Bey'in yere diz çökerek af dilediği sahne görülebilir. Sultan Mehmet ayakta, Karamanoğlu İbrahim Bey ise yerde diz çökmüştür. Çerçevenin önünde duran kılıç, sahnenin tüm anlamını değiştirmektedir. Seyircide, çerçevenin önünde duran kılıcın Sultan Mehmet tarafından kullanılacağı algısı oluşur. 
Haliç boğazına halatların gerdirilmesi sahnesinin ilk planı, hem kamera hem de görsel estetik olarak haz veren çekimler arasında sayılabilir. Yuvarlak bir çemberin etrafında on iki askerin halatı gerdirdikleri sahnede, askerlerin aksi yöne doğru dairesel hareket yapan kamera bu kullanımı filmin en etkili görüntülerindendir. Bu sahnede askerlerin hareketiyle kameranın hareketinin farklı yönlere yapılması estetik hazzı artırmaktadır.

Sinema filmlerinde en çok dikkat edilmesi gereken kural aks çizgisi kuralıdır. Özellikle savaş sahnelerinde yönetmenlerin çok kolay aks çizgisini atladıkları görülmektedir. Zaman zaman yönetmenler sahnenin anlamını güçlendirmek için aks çizgisini "bile isteye" atlayabilirler. Sultan Mehmet ve Ulubatlı Hasan arasında geçen diyalogda aks hatası yapan yönetmenin, aks çizgisini farkında olmadan atladığı anlaşılmaktadır. Kuşatmanın on ikici gününde Sultan Mehmet ve Ulubatlı Hasan'ın konuşmasında bir önceki planda çerçevenin solunda olan Ulubatlı Hasan, sahne sonundaki son çerçevede sağda durmaktadır. Bu hata ile hem Sultan Mehmet'in hem de Ulubatlı Hasan'ın bakış yönleri değişmiştir.

\section{Aydinlatma}

Dönemin şartları göz önünde bulundurularak yapılan sahne aydınlatmalarında Kelvin derecesinin mum ışı̆̆ı, gaz lambası ve ateşe göre ayarlandığı görülmektedir. Tüm gece sahnelerinde mum, gaz lambası ve ateşin görünür olmasının sebebi, sahnenin inandırıcılığıyla ilgilidir. Sahnede dekor olarak kullanılan mum, gaz lambası ve ateşten zaman zaman, sahne aydınlatması yapılırken de yararlanıldığı görülmektedir. Özellikle askerlerin açık havada üşümemek için yaktıkları ateşler, sahne aydınlatması için de kullanılmaktadır.

İstanbul'un uzun süren kuşatmasını ve sonrasında da fethini ele alan film, her ne kadar dış mekânda geçse de sahnelerin iç mekân ve dış mekân dağılımlarında bir dengenin olduğu söylenebilir. Filmin aydınlatması, dış mekân ve iç mekân aydınlatma prensipleri göz önüne alınarak yapılmıştır.

Filmin genelinde gündüz ve gece çekimleri arasındaki dağılıma bakıldığında ise, gündüz çekimleri sayıca daha fazladır. Elektriğin henüz icat edilmediği bir dönem filminde gece ve dışarıda yapılacak bir çekimin 
güçlüğünü dikkate alan yönetmen gün ışığından faydalanmak için çekimleri de ağırlıklı olarak gündüz yaparak gün ışığından faydalanmıştır.

Sultan Mehmet'in askerleri, Haçlı ordusuna katılmak üzere İstanbul'a gelen İmparatorun birliklerine Mora'da bir gece baskın düzenlerler. Gecenin karanlığında çekilen bu sahnenin aydınlatmasında silüet aydınlatma tekniği kullanılmıştır. Detayların kaybolduğu bu aydınlatma türünde ş̧ık kameranın önünden gelmekte, sahnedeki nesne ya da karakterler sadece temel hatlarıyla görülmektedir. Savaş sahnesinin silüet olarak aydınlatılması, bireysel kahramanlıkların değil, topluluğun ön plana çıktığı bir anlamı doğurmaktadır.

Renkler ve renklere yüklenen anlamlar da sahnenin anlamını dolaylı da olsa etkilemektedir. Osmanlı ordusunun sancak rengi kırmızıyken Haçlı ordusunun sancak rengi sarıdır. Güç, ihtiras ve kanın rengi olan kırmızı, şehitlerin kanlarıyla boyanan sancağın gönlere er ya da geç dikileceğine işarettir. Zayıflığın ve hastalığın rengi olarak bilinen sarı renk ise, yenilginin habercisidir.

Kuşatmanın on ikinci günü yapılan çatışmanın gece yapılması, ateş toplarının daha görünür olmasını beraberinde getirmekte ve filmin estetik yönünü güçlendirmektedir.

Bir odanın ortasında tahtadan yapılmış yemek masasında oturan Era ve Urban ustanın üzerlerine düşen 1şık, Rembrant aydınlatmasına örnek olarak gösterilebilir. Sahne aydınlatması ağırlıklı olarak loştur. Urban usta ve Era'nın üzerlerine düşen yumuşak ışık, onları fondan ayırmaktadır. Era'nın tekli yakın plan çekiminde arkasındaki pencereden yansıyan ışığın Era'nın saçlarına düşmesi, doğal bir fon ışı̆̆ı işlevi görmektedir. Sahnenin kahverengi olan ağırlıklı rengine karşılık Era'nın tutku ve aşkın simgesi olan kırmızı renkli elbisesi, sahnede onu daha ön plana çıartmaktadır.

İmparatorun Karamanoğlu Mehmet Bey'e gönderdiği elçileri takip eden Ulubatlı Hasan ve arkadaşlarının ormanda geçiş yolunda elçilere yaptıkları baskın sahnenin renk ayarlarıyla kurgu aşamasında oynanmıştır. Sahnede orijinal rengin yerini daha çok metalik maviye kaçan bir renk almıştır. Ağaçların arasından süzülen 1şık huzmeleri ise görüntünün estetik değerini artırmaktadır. 


\section{Ses}

Sinemada görüntülerle anlatılması teknik olarak zor olan bir takım şeyler ses ile anlatılmaktadır. Sinemada ses denildiğinde; konuşmalar, ses efektleri ve müzik akla gelir. Filmde karakterlerin kendi aralarında konuşmalarının yanı sıra, bir kaç yerde hikâyeyi anlatan üst sesin kullanılması filme belgesel havası katmaktadır. Film anlatısına zaman zaman bir üst sesin eşlik etmesi, karakterlerin mitolojik kahramana dönüşmelerinin önünü açmaktadır.

Filminde savaş sahnelerinin sıklığı nedeniyle ses köprüsü tekniğini kullanan yönetmen böylelikle sahneleri birbiri ardına bağlamaktadır. Filmde ses köprüsünün belirgin olarak kullanıldığı sahnelerden birisi; savaşın başlamasından önce duyulan davul sesleridir. Osmanlı ordusu, Anadolu Hisarı'nın önüne dayanarak İstanbul'u kuşatmıştır. Artık savaşın başlaması için Sultan Mehmet'in emri beklenir. Sahne iki ordu askerlerinin hazırda bekleyen bir dizi çekimiyle son bulurken görüntü yavaşça kararır. Görüntünün kararmaya başlamasıyla duyulan davul sesleri, askerleri ve seyirciyi savaşa hazırlamaktadır.

Sultan Mehmet ile Ulubatlı Hasan arasındaki kılıç sahnesi, doğal sesin kullanımı için güzel bir örnektir. Kılıçların birbirlerine vurmasından çıkan ses ile karakterlerin nefesleri ve istem dışı çıkardıkları sesler sertliği, şiddeti ve ölümü çağrıştırmaktadır. Bu sahnedeki şiddeti ve ölümü çağrıştıran kılıç sesine karşılık, kuşların cıvıltıları ve küçük süs havuzundan gelen su sesi dikkati çeker. Filmin sadece ses kanalı dinlendiğinde sahnenin bir savaş sahnesinden bir kesit olmadığını, dostane bir kılıç müsabakası olduğunu anlatan iki sesten birisi kuşların cıvıltısı diğeri ise su sesidir.

Sultan Mehmet, askerlerine kıldırdığı namazda on binlerce askerin eş zamanlı hareketlerinden çıkan sesler ve Sultan'ın 'Allah'u Ekber' sesi, düşman karargahında kurmaylarıyla toplantı yapan İmparatorun odasından duyulmakta ve düşmanın yüreğini titretmektedir.

Filmde müzik daha çok dramatik etkiyi artırmak için kullanılmıştır. Sahnedeki aksiyonu seyirciye yansıtmak isteyen yönetmen, kamerası yanında müziği de etkin bir şekilde kullanmıştır. Rumeli Hisarı'nın yapımı sahnesinde görüntüde kısa kesmelerle aksiyonu oluşturan yönetmen, müziği de kullanarak aksiyon etkisini artırmıştır. 
Müzik, seyircinin sahnede verilmek istenen mesajı algılamasını doğrudan etkilemektedir. Sahnede kullanılan diyaloglar, efektler ve müzik sayesinde yenilgi ya da başarı hissi ses ile seyirciye anlatılmaktadır. Filmde Ulubatlı Hasan'ın vurulduğu ve sancağı burçlara diktiği sahne, buna örnek olarak gösterilebilir. Ulubatlı Hasan'ın vurulmasından sonra savaş meydanından gelen tüm sesler geri planda kalır. Ulubatlı Hasan'a atılan okların havada ilerlerken duyulan rüzgar efekti ve okların vücuda saplandığında çıkan sesler seyirciler tarafından duyulmaktadır.

Sesin sinemada anlatıma doğrudan etki eden yapısı, sessizliği de büyük bir güce dönüştürmektedir. Haçlı ordusunun sancağını indirdikten sonra göğsünden de vurulan Hasan elindeki kırmızı sancağı kaleye dikmek için mücadele eder. Göğsünden yediği okla birlikte duyulmaya başlanan ağıt müziği, seyirciye Ulubatlı Hasan'ın bayrağı dikemeden şehit olacağını düşündürmektedir. Ulubatlı Hasan'ın gücünü toplayarak sancağı kaleye sabitlemesiyle birlikte aynı müziğe vurmalı çalgılar eklenir ve ağıt olarak başlayan müzik artık zaferi müjdelemektedir. Rüzgârın sancağı dalgalandırmasıyla birlikte müziğin ritmi artarak devam eder. Sultan Mehmet, İstanbul şehrinde coşkuyla karşılandığında da yine aynı müzik devam etmektedir.

\section{Kurgu}

Filmde bir plandan diğer plana, bir sahneden diğer sahneye geçmek en sık için tercih edilen geçiş türü kesme'dir. Özellikle savaş sahnelerinde, sahnenin aksiyonunu seyirciye aktarmak için kesme ile geçiş çok tercih edilmektedir. Kesmeden sonra filmde en çok kullanılan geçiş türü kararma açılmadır. Kararma açılma, sahneleri birbirine bağlarken aynı zamanda aradaki zamansal atlamaları da tolere etmesi bakımından önemlidir. Buna en güzel örnek; şehzade Mehmet'in doğum haberi geldikten sonra Padişah II. Murat'ın yakın plan yüz çekiminden sonra kararma açılma ile yönetmenin Saruhan Sancağına, şehzade Mehmet'in babasının vefat haberini aldığı zamana geçiş yapması gösterilebilir.

Filmde yönetmenin özel bazı nesneleri geçiş nesnesi olarak da kullandığı görülmektedir. Filmin başında hikâyeyi Medine'den Edirne'ye taşıyan Şahin'in gözünden yaptığı bu geçiş, filmin estetik değerini artırmaktadır. Yedinci yüzyılda Hz. Muhammed'in evinden başlayan 
hikâye 15. yüzyılda Edirne'ye kadar birkaç dakika içinde (üç dakika) taşınmıştır. Hikâyenin devamlılı̆̆ını anlatıcı ses ile sağlayan yönetmen, görsel olarak hikâyeyi de taşıdığı varsayılan kuşu (şahin) zamansal ve mekânsal geçişler için kullanmıştır.

Osmanlı askerlerinin ilk saldırısında surda bir delik açılmıştır. Guistiniani süratle bu deliği kapatmak için çalışır. Kamerasını surdaki deliğin hemen ardına koyan yönetmenin çerçevesi, delik kapandıkça daralmaktadır. Guistiniani'nin askerleri son taşı da deliğe koyduğunda perde tamamen kapanır.

160 dakikalık filmin neredeyse yarısı bilgisayar ortamında üretilmiş, hemen hemen her planı bilgisayar işleminden geçmiştir. Savaş meydanında askerlerin sayılarının çoğaltılmasından, haliç sularındaki gemilerin sayılarına, kuşatma sahnesindeki topların surları delmesinden, surlardan savrulan taş parçalarına, Medine, İstanbul ve Edirne şehirlerinin kuş bakışı çekimlerinden, kuş'un (şahin) şehirlerarasında uçarken geçtiği yollara kadar çeşitli kısıtlıklar nedeniyle elde edilemeyecek görüntülerin tamamı bilgisayar ortamında yapılmıştır.

Filmde bunların dışında bilgisayar ortamında hazırlanan sahneler de vardır. İmparatorun odasında yanan ateşler, bir gece yarısı Çandarlı Halil Paşa'nın evinin penceresinden görünen yağmur ve gök gürültüsü de bilgisayar ortamında hazırlanan diğer sahnelerdir. Fethin en büyük simgelerinden biri olan Şahi Topu'nun ateşlendikten sonra kameranın süratle ilerleyen topu takip ederek surlara çarptığı anı ve sur duvarının dağılması bilgisayar ortamında üç boyutlu olarak çizilmiştir.

Fetih hazırlıkları başladığında Gelibolu'da bulunan yüzlerce gemi de bilgisayar ortamında çoğaltılmıştır. Savaşın son sahnesinde on binlerce atlı birliğin dörtnala koşması, milyonlarda askerlerin hisara doğru yaptıkları hücumun üst açı çekimi bilgisayar teknolojisinin ürünüdür. Bu sahnede kamera kesme yapmadan yavaşça alçalıp soldan sağa doğru çevrindiğinde hisar duvarlarının aşıldığı görülmektedir. Kalenin duvarının patlaması, bir sağdan bir soldan onlarca ateş topun havada uçuşması ve toplarının düştükleri yerden alevlerin yükselmesi gibi birebir çekimi neredeyse imkânsız olan tüm sahneler bilgisayar ortamında yapılmıştır.

Filmde kullanılan görsel efektler, dünya sineması ile yarışır şekilde kullanılmıştır. Orman sahnesinde Ulubatlı Hasan'ın fırlattığı mızrağın, bir 
askerin ensesinden girip boğazından çıkması, filmde efekt kullanımının başarılı bir örneği olarak gösterilebilir. Mora savaşında, askerlerin kolları ve bacaklarına aldıkları kılıç yaraları, vücut kesiklerinden dışarıya fışkıran kanlar, bir askerin kolunun kopması ve bir diğerinin yüzüne inen tokmakla suratının dağılmasını çoğu zaman yavaşlatılmış çekimlerle gösterilir. Bu sahnelerdeki makyaj ve özel efekt kullanımı oldukça başarılıdır.

Yönetmen kurguda görüntülerin okuma hızını düşürerek karakterlerinin üstün meziyetlerine vurgu yapmıştır. Saruhan Sancağı sahnesindeki yavaşlatılmış görüntüler, Ulubatlı Hasan ile Sultan Mehmet'in kılıç talimini görsel bir şölene dönüştürmektedir. Bu sahnede kullanılan yavaşlatılmış çekimler, kılıç kullanmayı ve dövüş sanatını estetize etmektedir. Aynı şekilde Sultan Mehmet'in yine at üstünde giderken okla bir domuzu vurmasının özellikle yavaşlatılması, Sultan'ın askeri yetenekleri hakkında seyirciye bilgi vermektedir.

Filmdeki yavaşlatılmış görüntüler sadece karakterleri olumlamak için kullanılmaz. Dörtnala koşan Osmanlı askerlerinin atılan oklarla vurulmaları ve atların üzerlerinden düşmeleri yavaşlatılarak gösterilir. Buradaki yavaşlatılmış görüntüler ordunun verdiği kayıpları anlatmaktadır. Seyircinin sahnede yaşanan duygusal duruma odaklanması istenildiğinde de görüntü hızı düşürülmektedir. Ulubatlı Hasan'ın vurulmasının ardından görüntü hızının yavaşlatılması da buna örnek olarak gösterilebilir.

\section{Göstergebilimsel Çözümleme}

\section{Dizisel Çözümleme}

Fetih 1453 filminde Sultan Mehmet ile İmparator Konstantin arasındaki karşıtlık, hikâyenin omurgasını oluşturmaktadır. Bunun dışında Ulubatlı Hasan ve Giovanni Giustiniani, Zağanos Paşa ile Çandarlı Halil Paşa arasında kurulan karşıtlıklar hikâyenin devamını sağlamasının yanı sıra filmin ideolojisinin yavaş yavaş açığa çıkartılmasında da etkilidir.

Film en önemli iki karakterden biri Sultan Mehmet, diğeri yüzylllık bir geçmişe sahip Doğu Roma İmparatoru Konstantin'dir. İki karakter arasında kurulan ilişkide iyi-kötü, biz-öteki karşıtlığ 1 çok net bir şekilde görülmektedir. Kurulan karşıtlık ilişkisinde; filmde iyinin temsilcisi olan 
Sultan Mehmet her koşulda hakkı savunurken; anlatıda haksızlığı kendisine hak gören İmparator Konstantin ise kötü olanı temsil etmektedir.

Sultan Mehmet'in sarayı ile İmparatorun sarayı arasındaki karşıtlık da, iki karakter arasında kurulan karşıtlığ padişahının vezirleriyle konuştuğu oda sadeliğiyle dikkat çekerken; İmparator'un odası ihtişamıyla göz alıcıdır. Odanın girişinde sağda ve solda duran iki kadın heykeli, duvarlardaki resimler ve süslemeler İmparatorun sanat ile olan ilişkisinin gösterenleridir. Hem padişah Sultan Mehmet hem de İmparatorun sarayları oldukça büyüktür. İmparatora haber getiren elçinin yere çömelmesinin ardından görülen koridorun derinliği sarayın büyüklüğü hakkında bilgi vermektedir. Yönetmen benzer bir çekimi Osmanlı sarayında da kullanmıştır.

Sultan Mehmet ile İmparator arasındaki karşıtlığın görsel olarak en belirgin olduğu sahne, savaştan önce Sultan Mehmet ile İmparatorun birbirleriyle konuştukları sahnedir. Her iki kumandanın arkasında bulunan on binlerce asker, gücün ve iktidarın simgesidir. Bu durum diyaloglarla da desteklenir:

İmparator: Sizi sarayımda ağırlamak isterdim sultan hazretleri. Ancak oldukça kalabalık gelmişsiniz.

Sultan Mehmet: Misafirperverlĭginiz için sağ olun imparator hazretleri. O sarayda ben sizi ağırlamak için buraya geldim.

Imparator: Surlarımızın ve imanımızın tarihte hiçbir güç tarafindan aşılamadığ $\mathrm{l}$ hatırlatmak isterim sultan hazretleri.

Sultan Mehmet: Bizden sonra artık hiç kimseye bunu hatırlatmak zorunda kalmayacaksiniz.

Imparator: Şehrimizin surları bunları defalarca duydu. En son babanıda. Ama hepsi gibi o da yarım bırakıp gitmek zorunda kaldı.

Sultan Mehmet: Biz yarm kalanı tam etmeye geldik. Şehri teslim ederseniz halkmiz aileleri ve mallarıla birlikte her türlü rahatsızliktan uzak olacak huzur içinde geçimini temin edecektir.

Imparator: Bu durumda çok kan dökülecek. Sizin kanını.

Sultan Mehmet: Biz Kur'an'ın hükmüne uyduk.

Kuşatmanın on ikinci gününde de bir sonuç elde edemeyen Sultan Mehmet, şehit olan askerlerini toplu mezarlarda defnederken, İmparator ordusuna eğlence tertip eder. Osmanlı askerleri derin bir sessizlik içinde 
kayıplarına ağlarken, Haçlı ordusunun askerleri müzikler eşliğinde eğlenmektedirler. İyi ve kötü arasında kurulan karşıtlık müzik kullanımında da kendisini göstermektedir. Osmanlı ordusunun gösterildiği sahnelerde 'ney'in tınısı kullanılırken; Haçlı askerlerinin dans edip eğlendiği sahnelerde ise ud, keman, çello ve def'ten oluşan enstrümanlarla hareketli müzikler kullanılmıştır. Bu sahnelerin birinde ölüm ve acı varken, diğer tarafta hayat ve eğlence vardır. Kuşatma devam ederken yapılan ziyafet ve danslarla İmparatorun zevk düşkünü olduğu gösterilirken; Sultan Mehmet acıdan kıvranmakta, rüyalarında bile rahat edemez. Eğlence sahnesinde kısa bir konuşma yapmak için ayağa kalkan İmparatorun arkasında görülen Meryem Ana figürü, Haçlı ordusunun dayandığ teolojik arka planın göstergesi olarak okunmaktadır.

Filmdeki karşıtlıklardan birisi de dinler arasında kurulmuştur. Sultan Mehmet'in Rumeli'ye sur yapmasindan sonra Avrupa'da Papa'nın öncülüğünde büyük bir haçlı ordusunun kurulması filmdeki karşıtlıklardan birisidir. İmparatorun, Sultan Mehmet'e yazdığ1 mektupta "Karşınızda bir haçlı ordusu bulacaksınız" demektedir. Hikâyenin temelini İslam peygamberi Hz. Muhammed'e ve onun hadisine ${ }^{9}$ dayandıran yönetmenin film içinde sürekli olarak hadise atıf yapması, dini temele dayanan bu karşıtlığın altını çizmek anlamına gelmektedir.

Hristiyan ve İslam inançları arasındaki karşıtlığın haricinde filmde, Katolik Hristiyanlar ile Ortodoks Hristiyanlar arasında da bir karşıtlık söz konusudur. Papa'nın Haçlı Ordusu kurmak için Avrupa'daki Ortodoks kilisesinin Katolik kilisesine bağlanması ön şartı, Ortodokslar ve Katolikler arasında bir karşıtlığın filizlenmesini beraberinde getirmiştir. Grandük Notaras, büyük bir cesaret göstererek Papa'dan medet uman İmparatora; "Şehrimizde bir Latin külahı görmektense, Türk sarığ1 görmeyi tercih ederim." diyerek Papa ile yapılacak anlaşmanın sadece bir anlaşma olmayacağını, bu sayede Ortodoks kilisenin de Papa'nın emrine gireceğini hatırlatmıştır. İmparator, saltanatının geleceğini garanti altına almak için Ortodoks Papaz Genadius ve yandaşlarına baskı yapmaktan dahi kaçınmamaktadır.

\footnotetext{
9 'Istanbul Muhakkak Feth Olunacaktır. Onu Fetheden Komutan Ne Güzel Komutan Ve Onun Askeri Ne Güzel Askerdir'.
} 
İmparatorun on kişiden oluşan danışma konseyi içinde farklı düşünen Grandük Notaras, Padişah Mehmet'in gücünün küçümsenmemesi gerektiğini söyler. Olaylara gerçekçi yaklaşımıyla dikkat çeken Notaras; farklı fikirleri savunması açısından Çandarlı Halil Paşa ile benzerlik göstermektedir. Notaras ile Çandarlı Halil Paşa arasındaki en büyük ayrım ise; filmin sonunda Notaras'ın haklı çıkmasıdır.

Sultan Mehmet ile İmparator arasındaki bazı benzerliklerden de söz edilebilir. Güçlü olmaları, etrafındaki insanları ikna edebilmeleri ve askeri konulardaki yetenekleri bunlar arasında sayılabilir. Her iki komutanın da savaş öncesi danışmanlarıyla yaptıkları toplantılar ve harita üzerinden yapılan planlamalar birbirlerine benzemektedir.

Filmdeki bir diğer karşıtlık; Giustiniani ile Ulubatlı Hasan arasında kurulmaktadır. Yönetmen, savaş sahnelerinde bireysel olarak üstün yetenekleri olan bu iki karakteri ard arda kurgulayarak karşılaştırmaktadır. Giustiniani ne kadar korkusuz ve cesursa Ulubatlı da bir o kadar cesur ve korkusuzdur. Boyları, saç kesimleri, sakal tıraşları, giyimleri ve vücut yapılarıyla birbirlerine çok benzeyen bu iki karakter, kılıç kullanma ve askeri yetenekler konusunda da birbirlerine benzer.

Giustiniani ve Hasan'ın aynı kıza (Era) âşık olmaları başlı başına bir karşıtlık sebebidir. Milliyetçi ideolojinin olumladığı ideal erkek; kadınlar tarafından sevilen ve neslin devamını sağlayabilecek erkektir. Bu anlamda evlenme teklifi Era tarafından reddedilen (üstelik birkaç kez reddedilmiştir. Bu daha sonra Era'nın babasıyla yaptığı konuşmadan anlaşılmaktadır) Giustiniani daha filmin başında kaybetmiştir. Giustiniani yıllardır yalvarmasına rağmen Era'yı ikna edemezken; Ulubatlı Hasan çok kısa bir tanışıklığın ardından Era'nın gönlünün kahramanı olmuştur.

\section{Dizimsel Çözümleme ve Yananlam}

Ulubatlı Hasan ile Era'nın tanıştıkları Pazar yeri sahnesi, bir çocuğun elma tezgâhından bir elma alarak kaçması ile başlar. Sahnenin devamında Era ve Ulubatlı Hasan'ın çocuğa yardımı anlatılmaktadır. Sahnede, çocuğun onlarca meyve arasından Âdem'in yasaklı meyvesi olan elmayı çalması yan anlamsal olarak analiz edilmelidir. Filmde, Hz. Muhammed'in hadisi, Ebu Eyyüp El- Ensari'nin mezarı ve Fetih Suresi'nin okunması gibi dinsel referanslara yapılan çok köklü göndermeler göz önüne alındığında, 
çalınan elma insanlığın ilk günahına yapılan bir göndermedir. Çocuk elmayı izinsiz alarak yasaklı bir şey yapmış, kendisine ait olmayanı almıştır. Âdem de yasaklanan elmayı izinsiz alarak günah işlemiştir.

Sarayında oğlu Mehmet'in doğum haberini bekleyen Sultan II. Murat, Fetih suresini okumaktadır. İstanbul'un fethini konu alan filmde yönetmen Kuran'daki sureler arasından Fetih suresini tercih etmiştir. Daha filmin başında Fetih suresinin okunması, İstanbul'un fethini haber vermektedir.

Sultan Mehmet'in Osmanlı Devleti'nin kurucusu Osman Bey'i rüyasında görmesi ve ondan güzel sözler duyması, Sultan Mehmet'in gücünü artırmaktadır. Rüyasında Osman Gazi'nin kendisine yüzük verdiği bir anda yüzüğün kızgın ateşlere düşmesi iktidarın tam olarak sağlanamadığı anlamına gelmektedir. Sultan Mehmet İstanbul'u almadan gerçek bir Sultan olamayacaktır.

İstanbul'un fethi için yapılan hazırlıklardan rahatsız olan başta İmparator olmak üzere diğer Avrupalı ülkeler Sultan Mehmet'i fetih düşüncesinden caydırmak istemektedirler. Çandarlı Halil Paşa, Papa'nın usta bir okçu birliği ile büyük haçlı ordusuna destek vereceğini söyler. Çandarlı'nın bu sözleri sırasında ok talimi yapan Sultan Mehmet, hedefi on ikiden vurması, Papa'nın üstün meziyetli olarak övülen okçularından korkmadığının göstergesidir.

Doğu Roma İmparatoru, Karamanoğlu İbrahim Bey ve Şehzade Orhan'ın Osmanlı'nın önünü kesmek için birleştiklerini kır gezisinde öğrenen Sultan Mehmet, aniden okuyla çalıların arasındaki bir domuzu avlar. Sultan'ın böyle bir haberin ardından domuz avlaması, kendisine ihanet edenleri neye benzettiğini açık etmektedir.

Vatanperverliği ve cengâverliği örnek olarak gösterilen Ulubatlı Hasan'ın şehit olmasıyla Era'nın hamile olduğu bilgisini peş peşe veren yönetmen, milliyetçi ideoloji için kayıp gibi görünen bir durumu kazanıma dönüştürmektedir. Devleti ve milleti için canını hiçe sayan bir Ulubatlı giderken, ardından bin Ulubatlı gelmektedir. Milliyetçi ideolojinin devamının sağlanması için gelecek yeni nesillere ihtiyaç vardır. 


\section{Sonuç}

İstanbul'un Sultan Mehmet tarafından feth edilmesini anlatan filmde milliyetçi ideolojiyi yansitan birçok göstergeye başvurulmuştur. Filmde geniş okumalara imkân veren simgelerin/gösterenlerin işaret ettikleri anlamlardan bazen daha fazlasına karşlık geldiği görülmektedir. Filmde sık kullanılan simgeler arasında; sancak, bayrak, muska, yüzük, kılıç, gökyüzü, mektup vb. sayılabilir. Bireyin bir gruba üye olduğunu sürekli olarak hatırlatan bu simgeler birlikte yaşama istek ve iradesinin en güçlü göstergeleri olmanın yanı sıra, topyekûn milleti köklü bir tarihsel arka plana bağlamaları bakımından da önem arz etmektedirler.

Filmde dini göstergeler çok sık kullanılmıştır. Yönetmenin milleti meydana getiren unsurlardan 'din birliğine' özellikle vurgu yaptığı görülmektedir. Din konusunda kullanılan göstergeler arasında; Kur'an, cami, seccade, dua, namaz, tespih gibi İslam dinini işaret eden simgeler bulunmaktadır. Filmin hikâyesini dini referanslarla güçlendiren yönetmen peygamberin hadisini hikâyesi için çıkış kaynağı olarak kullanmış ve filme Mekke şehrinin görüntüleri ile başlamıştır. Ayrıca iki ordunun karşı karşıya gelmesinden hemen önce Sultan Mehmet'in orduya namaz kıldırması, ordunun peygamberin ordusu olarak nitelendirilmesine bir gönderme olarak okunmaktadır.

Sinemada anlamı güçlendirmek için kullanılan en önemli araçlardan birisi de yakın çekimdir. Filmde yönetmenin hikayenin dramatik etkisini artırmak ve seyirciyi bir düşünceye yönlendirmek için yakın çekime sıklıkla başvurduğu görülmektedir. Sinemada iç mekân aydınlatması ile dış mekân aydınlatması, gündüz aydınlatması ile gece aydınlatması hem teknik hem psikolojik hem de estetik açıdan farklılıklar içermektedir. Filmde kullanılan aydınlatmaya bakıldığında dış mekân, iç mekân, gündüz ve gece aydınlatma prensipleri göz önüne alınarak yapılmıştır. Filmde ağırlıklı olarak temel aydınlatma kaynağı olarak gün ışığından faydalanıldığı, çekimlerinde gün ışığını kontrol etmek ve yer yer desteklemek amacıyla da yapay aydınlatma kaynaklarının kullanıldığı görülmektedir. Gece çekimlerinde ise gölgelendirme ve ay ışığı etkisini elde etmek için aydınlatma kaynaklarına ek olarak renklendirici filtrelerin kullanıldığ1 tespit edilmiştir. Filmde gerilimi, heyecanı ve duygusal ortamı sağlamak için kurgunun sağladığı imkânlardan da maxsimum 
oranda faydalanılmıştır. Bir çekimden diğer çekime geçerken çoğunlukla herhangi bir geçiş efektinin kullanılmaması (kesme ile geçiş) filmin gerçekliğini artıran en önemli unsurdur. Özellikle savaş sahnelerinde, heyecan ve aksiyonu seyirciye aktarmak için kesme geçişlerin süreleri artırılmıştır.

Fetih 1453, milliyetçi söylemi inşa ederken sinemanın estetik öğelerini yerinde ve seyirciyi rahatsız etmeden kullanan örnek bir film olarak değerlendirilmektedir. 
EXTENDED ABSTRACT

\title{
The Construction of Nationalism and Cinema: The Case of the Conquest 1453
}

\author{
Mustafa Aslan \\ Aydin Adnan Menderes University
}

The invention of the printing press paved the way for nationalist thought to reach wide masses. In this way, the nationalist ideology started to influence the masses. Nationalism is a sociological concept. Nationalism has been evaluated as an outcome of social conditions and positioned as a phenomena that is separate and independent from society. One of the tools that reproduce nationalist discourse in social life is cinema. By isolating nationalist ideology from social life, it would be wrong to regard it as just a thought. In fact, nationalism affects life outside politics. In short, nationalist discourse exists in every aspect of life. National narratives, it tells that it belongs to a nation that has to be proud of the new generation and keeps the individual within the boundaries drawn by the nationalist ideology. Mass media; radio, television, newspaper, cinema and social media, the most effective way of setting the agenda and creating perception for the society and society. These tools are important for the reproduction of nationalist ideology as well as other ideologies. The movies which come out at the same time in the four corners of the world can transmit the realities which they try to build to large masses, and the stories themselves can be an ideological vehicle by using universal indicator systems.

In Turkish cinema, nationalist films have increased in number in recent years. Almost infinite number of indicators used in the cinematic narrative and aesthetic understanding affects directly the meaning of the movie. The deduction of the indicators used in Turkish Cinema movies functioning nationalistic themes and esthetics understanding constitute the primary objective of the study. In this context, Fatah 1453 film will be analyzed and how the nationalist discourse is constructed. Describing a period in Turkish history, Fetih 1453 film will be examined through semiotic method. Semiotics is a method that helps us better understand the events 
we encounter in life. Semiotics reveals the meaning behind the image. It is a very convenient method to understand cinema. Because the movies tell the story of the images. The film tells the conquest of Istanbul by Sultan Mehmet. There are many symbols in the film about nationalist ideology. And the meaning of these symbols is changing according to the scenes used. Some of the symbols commonly used in the film are; starboard, flag, amulet, ring, sword, sky, letter etc. These symbols remind the audience that they are members of a group.

The most important element that constitutes the nation is the unity of religion. Religious indicators are used frequently in the film. The director wanted to create a sense of unity in the audience. A special emphasis has been placed on religious unity in the film. Religious symbols; Qur'an, mosque, prayer rug, prayer, prayer, rosary, etc. It is seen. The film already begins with the appearance of the city of Mekke. At the beginning of the film, the director referred to the prophet. It is also an important sign that Sultan Mehmet worshiped the soldiers together.

In cinema, close-ups are used to strengthen the meaning. Used to increase the dramatic effect of the story and close-up to impress the audience. Lighting is also important in cinema. outdoor lighting, daylight lighting and night illumination are both technically and psychologically different. Looking at the lighting used in the film, outdoor, indoor, day and night lighting principles were taken into consideration. In the film, daylight is mainly used as the main lighting source. Some devices are used for the moonlight effect at night shots music and other techniques were used to create tension, excitement and emotional environment. Particularly in the battle scenes, special planning was made to transfer the excitement and action to the audience.

Colors affect the meaning of the scene as well as other elements. The flag of the Ottoman army is red and the flag color of the Crusader army is yellow. Red color represents power, passion and blood. Also red color represents martyrs. Yellow is the color of weakness and disease.

Most of the film was made with computer support. For example, visual efects, colors and decor are made with computer support. Tens of thousands of soldiers were seen in some scenes in the film. The visual effects in the film are beautifully prepared. These efects are among the best examples of world cinema. In the film, the soldiers' arms and legs break, 
squirting blood, the scattering of her face and the slowed image is a visual feast.

Consequently, Fetih 1453 film reconstructs the nationalist ideology. In doing so, the film uses the aesthetic elements of cinema in place and does not disturb the audience. In this respect, the film can be shown as an example.

\section{Kaynakça / References}

Akdoğan, B. (2001). Sanat, sanatçı, sanat eseri ve ahlak. Ankara Üniversitesi İlahiyat Fakültesi Dergisi, 42 (1), 213-245.

Anderson, B. (1993). Hayali cemaatler milliyetçiliğin kökenleri ve yayılması. (İ. Savaşır, Çev.). İstanbul: Metis Yayınları.

Andrew, J. D. (2010). Büyük sinema kuramları. (Z. Atam, Çev.). İstanbul: Doruk Yayınları.

Arnheim, R. (2002). Sanat olarak sinema. (R. Ünal, Çev.). İstanbul: Öteki Yayınevi.

Atabek, Ş. G. (2007). Göstergebilimsel çözümleme iletişim çalışmalarında göstergebilimsel yöntem. G. Ş. Atabek ve Ü. Atabek (Ed.), Medya Metinlerini Çözümlemek. İçerik, Göstergebilim ve Söylem Çözümleme Yöntemi (367-376). Ankara: Siyasal Kitapevi.

Ataman, S. (1977). Milliyetçilik ve Türkiye. İstanbul: Kervan Yayınları.

Balazs, Bela (1968). Film kuramı (A. Göktürk, Çev.). Türk Dili Sinema Özel Sayısı, 1(196), 303-308.

Baradat P. L. (2012). Siyasal ideolojiler kökenleri ve etkileri. (A. Aydın, Çev.). Ankara: Siyasal Kitapevi Yayınları.

Barbaro, U. (1968). Özgür ve özerk bir yaratma (T. Saraç, Çev.) Türk Dili Sinema Özel Sayısı, 1 (196), 349-351.

Barthes, R. (1979). Göstergebilim ilkeleri. (B. Vardar ve M. Rifat, Çev.). Ankara: Kültür Bakanlığg Yayınları.

Bordwell, D. ve Thompson, K. (2008). Film art an introduction. New York: McGraw-Hill Companies.

Budak, A. (2006). Türk resminde yeni dışavurumculuk. Yayınlanmamış Yüksek Lisans Tezi, Atatürk Üniversitesi, Erzurum, Türkiye. Büker, S. (1991). Sinemada anlam yaratma. Ankara: İmge Kitapevi. 
Calhoun, Craig (2007). Milliyetçilik. (B. Sütçüoğlu, Çev.). İstanbul: İstanbul Bilgi Üniversitesi Yayınları.

Can, A. ve Esen, H.(2008). Kısa filmde ritm. Selçuk Üniversitesi Sosyal Bilimler Enstitüsü Dergisi, 19, 153-165.

Candan, E. (2006). Türkler'in kültür kökenleri. İstanbul: Sınır Ötesi Yayınları. Dmytryk, E. ve Edward, J. P. (2007). Sinemada yönetmenlik, oyunculuk, kurgu. (İ. Şener, Çev.). İstanbul: Doruk Yayınları.

Eisenstein, S. M. (1984). Film duyumu. (N. Özön, Çev.). İstanbul: Payel Yayınevi.

Erdoğan, İ. ve Solmaz, B. P. (2005). Sinema ve müzik materyal satış ve bilinç yönetimi için bilişsel ve duyusalın oluşturulması. Ankara: Erk Yayınlar1.

Fiske, J. (1996). İletişim çalışmalarına giriş (S. İrvan, Çev.). Ankara: Bilim Sanat Yayınları.

Güçhan, G. (1992). Toplumsal değişme ve Türk sineması. Ankara: İmge Kitapevi.

Gültekin, Z. (2006) Irak'dan önce: Kurtlar vadisi dizisi. İletişim Kuramları Dergisi, 22, 9-36.

Güney, A. (2006). Resmi milliyetçilikten popüler milliyetçiliğe geçiş: 1960 sonrası Türk sineması üzerine siyasal bir deneme. Doğu Batı, 1(39), 209-226.

Heywood, A. (2006). Milletler ve milliyetçilik. B. Kalkan (Ed.), Siyaset (151-180). Ankara: Liberte Yayınları.

Kafesoğlu, İ. (2010). Türk milli kültürü. İstanbul: Ötüken Yayınevi.

Kaplan, M. (1977). Türk milletinin kültürel değgerleri. İstanbul: Milli Eğitim Basımevi.

Kedourie, E. (1971). Avrupa'da milliyetçilik. (M. H. Timurtaş, Çev.). Ankara: Milli Eğitim Bakanlığg Basımevi.

Köseoğlu, N. (2003). Türk milliyetçiliği ideolojisinin doğuşu ve özellikleri. T. Bora ve M. Gültekin (Ed.), Modern Türkiye'de Siyasi Düşünce (208-225). İstanbul: İletişim Yayınları.

Özön, N. (1972). 100 soruda sinema sanatı. İstanbul: Gerçek Yayınevi.

Özön, N. (1984). Önsöz. N. Özön (Ed.). Film duyumu (VII-CLXC). İstanbul: Payel Yayınevi.

Özön, N. (1985). Sinema uygulayımı-sanatı-tarihi. İstanbul: Hil Yayınları. 
Parsa, S. ve Parsa, F. A. (2002). Göstergebilim çözümlemeleri. İzmir: Ege Üniversitesi Yayınları.

Platon (2008). Devlet (S. Eyüpoğlu ve M. A. Camgöz, Çev.). İstanbul: Türkiye İş Bankası Kültür Yayınları.

Rifat, M. (2009). Göstergebilim ABC'si. İstanbul: Say Yayınları.

Roux, J. P. (2007). Türklerin tarihi pasifik'ten akdeniz'e 200 yll. (A. Kazancigil ve L. A. Özcan) İstanbul: Kabalcı Yayınları.

Saussure, F. (1976). Genel dilmilim dersleri I. (B. Vardar, Çev.). Kaliteli Basımevi: Ankara.

Sebeok, A., Thomas (2000). Göstergebilime giriş. (M. Rifat ve S. Rifat, Çev.). XX. Yüzyılda Dilbilim ve Göstergebilim Kuramları 2. Temel Metinler (270-273). İstanbul: Om Yayınevi.

Smith, D. A. (1986). The ethnic origins of nations. Oxford: Blackwell.

Sözen, M. (2003). Sinemada ses kullanımı. Ankara: Detay Yayıncilık.

Thompson, K. ve Bordwell, D. (2003). Film history an introduction. United States: McGraw-Hill Companies.

Yalsızuçanlar. S. (2010). Türk sinemasında yerli bir damar: Yücel Çakmaklı. A. Şen (Ed.), Türk Sinemasında Yerli Arayışlar (367-376). Ankara: Türkiye Cumhuriyeti Kültür Bakanlığı.

\section{Kaynakça Bilgisi / Citation Information}

Aslan, M. (2019). Milliyetçiliğin inşası ve sinema: Fetih 1453 filmi örneği. OPUS-Uluslararası Toplum Araştırmaları Dergisi, 11(18), 2337-2372. DOI: 10.26466/opus.535594 